\title{
La escultura conmemorativa española en el siglo XIX a través de las revistas artísticas del reinado isabelino
}

\author{
The Spanish memorial sculpture in the 19th \\ Century through the art journals of the \\ Elizabethan reign
}

\author{
María Victoria ÁLVAREZ RODRÍGUEZ \\ Universidad de Salamanca
}

Recibido: 14-V-2014 / Aceptado: 30-VI-2014

RESUMEN: De entre todas las tipologías escultóricas que se desarrollaron en nuestro país durante el reinado de Isabel II, la conmemorativa de carácter público es probablemente la más interesante a la par que la más encumbrada por aquel entonces. Desdeñada durante buena parte del siglo XX como una de las plasmaciones más elocuentes del espíritu académico decimonónico, gozó sin embargo de una aceptación plena por parte de la sociedad isabelina, que veía en ella no solamente un objeto artístico digno de admiración sino también el catalizador de las creencias, valores y virtudes de un pasado que se pretendía recuperar en aras del creciente nacionalismo. Nos proponemos analizar el modo en que estos monumentos eran descritos en publicaciones tan paradigmáticas como El Mundo Pintoresco, Semanario Pintoresco Español o La Revista de Bellas Artes, que actuaron tanto como receptoras de las inquietudes culturales del momento como de instrumentos de adoctrinamiento.

Palabras clave: Siglo XIX, España, Isabel II, Escultura, Prensa

ABSTRACT: Of all the sculptural typologies developed in our country during the reign of Isabel II, the memorial public sculpture is probably the most interesting and the most valued at that time. Having been ignored for much of the $20^{\text {th }}$ Century as one of the most eloquent manifestations of Nineteenth-Century academic spirit, it enjoyed yet acceptation by the Elizabethan society, who saw in it not only an artistic object worthy of admiration but also the catalyst of the beliefs, values and virtues of a past that it sought to recover for the sake of the growing nationalism. We intend to analyze how these monuments were described in publications such as El Mundo Pintoresco, Semanario Pintoresco Español or La Revista de Bellas Artes, who acted both as recipients of the cultural concerns of the moment as well as methods of indoctrination.

Keywords: 19th Century, Spain, Isabel II, Sculpture, Press

Hablar de la escultura conmemorativa desarrollada en España entre 1833 y 1868 equivale a hacerlo de una de las manifesta- ciones artísticas más representativas de toda la centuria. Convertidos en símbolos de una ciudad, elementos icónicos de su urbanismo 
y recordatorios de las antiguas hazañas realizadas por sus paisanos, los monumentos que se erigieron en nuestro país en el siglo XIX constituyen un tema de estudio realmente poliédrico que podría abordarse desde perspectivas muy distintas, sobre todo si tenemos en cuenta la riqueza discursiva de la que fueron dotados desde el primer momento y la enorme trascendencia, inmediata en la mayoría de los casos, que alcanzaron de cara a la sociedad. No podemos olvidar que, cuando hablamos de escultura conmemorativa, nos referimos a una tipología concreta cuya función artística (entendida como un deleite sensorial, como parte de un proyecto de embellecimiento de una ciudad, por ejemplo) no era lo único que la hacía meritoria a ojos de la sociedad, sino también la posibilidad de emplearla como vehículo de difusión de las ideas que se quería inculcar a los ciudadanos.

El adoctrinamiento, en efecto, estuvo vinculado a los monumentos públicos desde el principio de los tiempos, y el siglo XIX no fue una excepción en este sentido. Es fácil comprender por qué la corona española decidió servirse de esta herramienta como una manera más de legitimar su poder, y también por qué su carácter institucional alcanzó un desarrollo tan incuestionable que el valor artístico de las obras, como acabamos de señalar, quedó bastante ensombrecido en muchos casos. Esto llevó entre otras cosas a que durante buena parte del pasado siglo la escultura conmemorativa fuera desdeñada por los historiadores del arte, para quienes era la perfecta plasmación del academicismo de un período considerado de mucho menor interés que sus antecesores. Sin embargo, la recuperación del arte decimonónico español que se ha venido llevando a cabo durante las últimas décadas ha permitido contemplarla desde un prisma diferente, acercándonos cada vez más a la elevada consideración de la que gozaba por parte de la sociedad isabelina $^{1}$.

${ }^{1}$ C. REYERO, La escultura conmemorativa en España. La edad de oro del monumento público, 1820-1914, Madrid,
Por supuesto, esa consideración encontró su eco en las publicaciones dedicadas a las Bellas Artes durante el reinado de Isabel II. A lo largo de esas tres décadas fueron muy numerosos los estudios, discursos y debates que se realizaron sobre el tema, lo que desde el primer instante se hizo extensivo al ámbito de la prensa artística. Aunque el análisis de la relevancia que las publicaciones periódicas tuvieron en ese momento, y su extraordinario desarrollo, sea un tema que excede el presente estudio, creemos necesario aclarar que el examen de los artículos que vieron la luz en revistas tan conocidas como el casi mítico Semanario Pintoresco Español, o la más moderna y actualizada Revista de Bellas Artes e Histórico-Arqueológica, permite arrojar un poco más de luz sobre la concepción que la sociedad isabelina tenía de estos monumentos. Y lo que resulta aún más importante si pretendemos abordar la cuestión desde un punto de vista teórico, sobre las poderosas implicaciones nacionalistas de los mismos, siempre atendiendo a un afán por recordar a la sociedad española que tenía motivos para sentirse orgullosa del pasado de su país. En el fondo este mecanismo no se diferenciaba mucho del adoctrinamiento que se trataba de llevar a cabo con la pintura de historia, que, además de instruir a quien contemplara los cuadros, pretendía demostrar que aún era posible recoger el testigo de personajes tan admirables como los Reyes Católicos, Cristóbal Colón o los Comuneros².

Todas estas ideas quedaron perfectamente plasmadas en los artículos publicados en las revistas de las que acabamos de hablar. Lo más habitual era que estos textos se dedicaran a describir el monumento conmemorativo en cuestión, explicando cuáles habían sido las virtudes del representado y cómo se había ganado el derecho a convertirse en modelo de inspiración para los españoles. No obstante, a menudo nos encontra-

1999, pp. 7-8.

2 Sobre este particular recomendamos consultar la tesis doctoral de T. PÉREZ VIEJO, Pintura de historia e identidad nacional en España, Madrid, 2001. 
mos con textos mucho más interesantes que se detienen, aunque no sea más que en unas pocas líneas, a analizar lo meritorio que era que el gobierno de Isabel II se tomase en serio su obligación para con la sociedad en este sentido. "Nunca son tan justos los pueblos y los gobiernos", sostenía por ejemplo M. C. de R. en un artículo dedicado a una escultura de Murillo de la que nos ocuparemos más tarde, "como cuando perpetúan por medio de monumentos públicos la memoria de los hombres que habiendo dado prez y honra á su patria son gloria de la humanidad entera" ${ }^{3}$. En opinión del autor, había que esperar a que el paso del tiempo pusiera a cada uno de estos personajes en su sitio, de modo que, con cierta distancia, se pudiera comprobar si realmente eran merecedores de tantos honores:

"La pasion y mucho menos los intereses de bandería no deben jamás tener parte en esos mudos, pero elocuentes testimonios del respeto, de la admiracion y de los homenajes á que se han hecho acreedores los hombres célebres en virtud, en letras, en armas ó en artes. Por eso es necesaria la solemne sancion del tiempo para aquilatar el verdadero mérito, universalmente reconocido, y por eso no hay obstáculos al proyectarse monumentos en honor de aquellos cuya inaccesible gloria nadie ha osado amenguar" ${ }^{\prime 4}$.

Tampoco faltaban las voces que añadían que la importancia de estos monumentos residía en algo más que en su capacidad de transmisión de valores. El autor anónimo de un texto publicado en El Mundo Pintoresco el 26 de enero de 1867 coincidía con lo que M. C. de R. había opinado, pero añadía que, desde un punto de vista urbanístico, "para que un paraje público lo sea, en la extension legítima de la frase, es necesario que contenga cosas que lo constituyan en tal" ${ }^{\prime \prime}$. La escul-

${ }^{3}$ M. C. de R., "Monumento á Bartolomé Esteban Murillo", El Mundo Pintoresco, tomo II, nº 13, 27 de marzo de 1859, p. 99.

\footnotetext{
${ }^{4}$ Ibídem.

5 "Más sobre la erección de un monumento á Colón, Cortés y Pizarro", La Revista de Bellas Artes, tomo I, nº 17,
}

tura conmemorativa sería, según su opinión, un requisito sine qua non en este sentido, de manera que poseería una suerte de doble naturaleza: por un lado apelaría a "la gloria y el noble orgullo de los pueblos", y por otro serviría "á la utilidad material, al mercantilismo del procomun, á la creacion de una fábrica que, en vez de constituir sitio de compra y venta, constituye núcleo de poblacion, centro fabril de cosas, abrigo y pretesto del ensanche de la ciudad" ${ }^{\prime}$. Y esta opinión sería la misma que se mantendría durante las últimas décadas del siglo XIX y comienzos del XX, sumada a la consideración de que, al igual que los grandes lienzos de historia en el campo de la pintura, la realización de un monumento conmemorativo era por aquel entonces el punto culminante en la carrera de un escultor. En ambos casos nos encontraríamos ante una obra de arte que inmortalizaría no solo al representado sino también a su artífice, granjeándole los mayores laureles en su especialidad. Sirva como ejemplo de esta creencia el discurso dedicado al monumento público con el que Miquel Blay i Fàbregas ingresó en la Real Academia de Bellas Artes de San Fernando en 1910:

"Suprema obra de arte unas veces, que figura entre las mas soberanas y colosales creaciones del genio, y menguada expresión de un símbolo generoso, otras, el monumento público se muestra, a través de la Historia, desde los más remotos tiempos, por los pueblos y las razas todas, como documento expresivo y elocuente de las distintas civilizaciones; atestiguando siempre con sus masas y trazados, cuáles son los más altos ministerios y destinos de la vida del hombre"7.

Como podemos comprobar, la prensa artística se convirtió en receptora de muchas

\footnotetext{
26 de enero de 1867, p. 135.

${ }^{6}$ Ibídem.

${ }^{7}$ M. BLAY I FÀBREGAS, El monumento público. Discursos leídos ante la Real Academia de Bellas Artes de San Fernando en la recepción pública del Excmo. Sr. D. Miguel Blay el día 22 de mayo de 1910, Madrid, 1910, pp. 12-13.
} Cfr. en C. REYERO, Op. cit., pp. 133-134. 
de estas opiniones, y no resulta complicado seguir un discurso más o menos detallado al respecto durante los años en que Isabel II ostentó la corona. En el presente estudio nos proponemos trazar una panorámica de los artículos que consideramos más esclarecedores, o que se ocupaban de los monumentos españoles más icónicos. Para ello hemos optado por dividir nuestro análisis en cinco apartados, atendiendo a la tipología escultórica de la que se ocupaban esos textos: en primer lugar estudiaremos los dedicados a la monarquía pasada y presente, en segundo lugar a los personajes históricos más relevantes, en tercer lugar a las representaciones de los grandes héroes de la patria, en cuarto lugar a las personalidades de la Iglesia, y en quinto y último lugar a las que destacaron en el campo de la cultura. Aunque diferentes en cuanto a su temática, el espíritu que animaba a estas empresas era similar, y se encontraba en consonancia con el nacionalismo que recorría nuestro país por aquel entonces. Mediante la disposición de estas esculturas dentro del trazado urbano de las ciudades modernas, los protagonistas de las grandes gestas de antaño eran inmortalizados a ojos de la sociedad, convirtiéndose en el espejo en el que los españoles no tenían más que mirarse para recordarse a sí mismos que podían sentirse orgullosos de sus raíces.

\section{LAS ESCULTURAS CONMEMORATI- VAS DE LA MONARQUÍA}

Al ocuparnos de los monumentos dedicados a la monarquía, conviene tener en cuenta que estaríamos hablando del apartado más indudablemente propagandístico de la escultura conmemorativa. El sentido de muchas de estas obras, sobre todo en el caso de las que representaban a personajes contemporáneos, estaba directamente relacionado con el proceso de adoctrinamiento de la sociedad, enfocado a convertirlos en modelos de inspiración dotándolos para ello de toda clase de virtudes morales que probablemente no poseyeron nunca. Por supuesto, este fenómeno no se dio solamente en nuestro país, sino que todo el continente europeo fue sembrado durante el siglo XIX de monumentos semejantes, en clara relación con los turbulentos cambios políticos que se produjeron a lo largo de la centuria, y que hicieron absolutamente necesaria una reafirmación de los grandes líderes mediante iniciativas de este tipo. En la prensa artística española pueden encontrarse numerosos ejemplos de esto, con noticias sobre la inauguración de estatuas pertenecientes a miembros de las coronas extranjeras como el príncipe Alberto en el caso de Inglaterra ${ }^{8}$, Pedro IV en el de Portugal $^{9}$, el emperador Maximiliano en el de Italia ${ }^{10}$, Leopoldo I en el de Bélgica ${ }^{11}$, Jorge de Podiebrad en el de Bohemia ${ }^{12}$, Guillermo III en el de Prusia ${ }^{13}$ y Pedro el Grande en el de Rusia ${ }^{14}$. Por lo general solían ser textos muy breves, simples anuncios en los que se contaba dónde habían sido erigidas estas esculturas, y como mucho algún comentario sobre sus ceremonias de inauguración, sin mencionar más que de pasada los nombres de los artistas que las habían llevado a cabo.

Centrándonos en el caso español, es interesante que la prensa artística no recogiera solamente noticias sobre la realización de monumentos modernos, sino también sobre el traslado de esculturas anteriores a las

\footnotetext{
8 "Crónica general", Revista de Bellas Artes e Histórico-Arqueológica, tomo II, no 58, 21 de noviembre de 1867,
} p. 111.

9 "Noticias de la Exposición Universal", La Revista de Bellas Artes, tomo I, no 27, 7 de abril de 1867, p. 215 y "Artes y arqueología", La Revista de Bellas Artes, tomo I, no 31, 5 de mayo de 1867, p. 247.

10 "Artes y arqueología", La Revista de Bellas Artes, tomo I, no 44, 31 de agosto de 1867, p. 359.

11 "Noticias de la Exposición Universal”, La Revista de Bellas Artes, tomo I, nº 27, 7 de abril de 1867, p. 215 y "Crónica general", La Revista de Bellas Artes, tomo I, no 47, 31 de agosto de 1867, p. 384.

${ }^{12}$ Nota aparecida en Semanario Pintoresco Español, no 51, 21 de diciembre de 1851, pp. 404-405.

13 "Artes y arqueología", La Revista de Bellas Artes, tomo I, no 28, 14 de abril de 1867, p. 222.

14 "Estátua ecuestre de Pedro el Grande", Semanario Pintoresco Español, no 47,18 de noviembre de 1855, p. 369 y "El monumento de Pedro el Grande", Semanario Pintoresco Español, no 48, 25 de noviembre de 1855, p. 383. 
cuales se decidió dar un emplazamiento más noble durante el reinado de Isabel II. También esto poseería un carácter propagandístico de incuestionable importancia, como queda patente en la colocación de la estatua ecuestre de Felipe III en la Plaza Mayor de Madrid. Esta obra era de factura italiana; el vaciado en bronce había sido realizado en 1616 por Giambologna, tomando como referencia un retrato de Pantoja de la Cruz del monarca, y concluido más tarde por Pietro Tacca. Fue un regalo de Cosme de Médici, Gran Duque de Florencia, lo que la convertía en una obra de indudable importancia tanto artística como diplomática, aunque su relevancia dentro del urbanismo madrileño no se produjo hasta ese traslado definitivo a la Plaza Mayor del que se habla en la inscripción de su pedestal ${ }^{15}$. También en El Renacimiento del 2 de mayo de 1847 encontramos una mención sobre este asunto, en la que se apuntaban algunas ideas de interés sobre cuál sería su disposición más adecuada:

“Dícese que pronto se trasladará desde la Real Casa de Campo á la plaza mayor de Madrid la estátua ecuestre de bronce de Felipe III, que, aunque bella, es muy inferior en mérito á la de Felipe IV que está adornando la plazuela de Oriente. Desearíamos que no la empingorotasen tan cerca de las nubes, como se ha solido hacer, sobre un pedestal demasiado alto; nos parece que la altura del que se le destinaba en el parterre del Real Sitio del Retiro es la que debiera conservarse. Esta clase de obras pierden la mitad de su mérito y de su efecto si se ven tan á vuelo de sapo. Debe tenerse algo en cuenta su mérito artístico, su ejecucion, su belleza respectiva"16.

En cuanto a la estatua de Felipe IV que se mencionaba en este mismo artículo, en Se-

\footnotetext{
${ }^{15}$ En él puede leerse: "La reina doña Isabel II, a solicitud del Ayuntamiento de Madrid, mandó colocar en este sitio la estatua del señor rey don Felipe III, hijo de esta villa, que restituyó a ella la corte en 1606, y en 1619 hizo construir esta plaza Mayor. Año de 1848".

16 "República de artes y letras", El Renacimiento, nº 8, 2 de mayo de 1847, p. 64
}

manario Pintoresco Español se había hablado de ella once años antes, aunque por entonces no se encontraba en el emplazamiento que aparecía citado en El Renacimiento, la Plaza de Oriente, sino en un rincón del Parque del Retiro que a muchos españoles les parecía indigno tratándose de aquel monarca. Vuelve a ser una estatua ecuestre, una de las más notables en su género, fundida una vez más por Pietro Tacca entre 1634 y 1640, aunque sirviéndose en esta ocasión de retratos del rey realizados por Velázquez y por Martínez Montañés, y contando además con la colaboración de Galileo Galilei en lo tocante a la estabilidad de este atrevido diseño. Pero al igual que había sucedido con la estatua de su padre, la de Felipe IV tampoco pudo contar con una ubicación que hiciera justicia al retratado hasta que en el siglo XIX esta cuestión cobró una mayor importancia.

"Sensible es, en efecto", afirmaba a este respecto el autor de una breve nota que vio la luz en el Semanario Pintoresco Español del 5 de marzo de 1847, "que una obra de mérito tan insigne, y que debería campear para decoro de la poblacion en una de sus plazas, ó en la misma de la entrada del sitio del Buen Retiro, se halle como desterrada en un jardin reservado donde solo puede disfrutarse rara vez su vista"17. También en este caso hubo críticas para el pedestal, tildado de "mezquino de fábrica" y cuya sencillez, según este autor, "contrasta visiblemente con la suntuosidad de la estátua"18.

Más cercana en el tiempo, aunque siguiera sin ser una obra del siglo XIX, era la estatua ecuestre de Carlos IV erigida en México a finales de la centuria anterior. En este caso se trataba de un bronce realizado entre 1793 y 1802 por iniciativa de Miguel de la Grúa Talamanca, Virrey de la Nueva España, en un claro intento de adular al monarca español. La propia prensa artística se hacía eco de esto; por ejemplo, la descripción

\footnotetext{
17 "Estatua de Felipe IV en el sitio del Buen-Retiro", Semanario Pintoresco Español, tomo II, no 49, 5 de marzo de 1837 , p. 74.

${ }^{18}$ Ibídem.
} 
que publicó el Semanario Pintoresco Español del 30 de agosto de 1846 acerca de la obra no dudaba en recalcar lo mucho que México debía a este monarca, lo que quedaba patente en la iconografía de un monumento que manifestaba, "en todas sus bellas actitudes", que estaba sosteniendo "al Monarca mayor del universo, y tributando con sus propias divisas el homenaje debido al que por todas cuatro partes estiende sus dominios"19. Evidentemente, esta idealización estaba lejos de corresponderse con la realidad, y tenía por objeto realzar la figura de Carlos IV al igual que lo hacía la estatua, obra de Manuel Tolsá, y el diseño de la plaza en la que se colocó, de Antonio Velázquez ${ }^{20}$. El autor de este artículo, Emilio Tamarit, describía con gran detalle su fisonomía y su iconografía:

“El Rey está á caballo, vestido á la heróica, con el cetro en la derecha en ademan de mandar á un ejército, y tiene la cara vuelta hácia el palacio del Virey. El caballo está en actitud de andar pausadamente levantando la mano izquierda y el pié derecho, con la cabeza inclinada hácia la izquierda para hacer contraposición exacta con el Rey, cuyo traje consiste solo en un gran paño sujeto con una banda que le cruza el pecho, y tiene ceñida la frente con una hermosa corona de laurel. La altura del caballo es de tres varas y media, á que agregada la del ginete, componen ambas la de cinco varas y tres cuartas.

${ }^{19}$ E. TAMARIT, "Viajes. Estátua ecuestre del Rey Carlos IV en Méjico", Semanario Pintoresco Español, tomo I, no 35, 30 de agosto de 1846, p. 279.

${ }^{20}$ Este monumento, conocido popularmente en México como "El Caballito", ha sido objeto desde el día de su inauguración de numerosas críticas y ataques, debido principalmente al sentimiento antiespañol que acompañó al proceso de independencia mexicano y al detalle, considerado insultante, de que uno de los cascos del caballo estuviera pisoteando un carcaj azteca. Actualmente está siendo sometido a un proceso de restauración que trata de paliar los daños provocados por el ácido nítrico con el que fue tratado en una intervención anterior. B. MARÍN, "La restauración de El Caballito produjo daños irreversibles en la escultura", El País (en línea), 9 de octubre de 2013, consultado el 13 de mayo de 2014. URL: http://cultura.elpais.com/ cultura/2013/10/09/actualidad/1381295517 580837.html
Este es uno de los monumentos mas bellos de toda la América, que al mismo tiempo que hermosea la gran plaza, sirve de recuerdo a los mejicanos del amor paternal y beneficencia de tan digno Monarca"21.

Continuando con los territorios de ultramar de la corona, nos encontramos con el que sería el primer monumento conmemorativo realizado durante el reinado isabelino del que se hablaría en la prensa artística: la estatua de Isabel II, precisamente, erigida en La Habana. Había sido realizada por el marsellés Philippe Garbeille en 1857 y dispuesta en el lugar que ocupaba una estatua semejante de Isabel II niña, fundida en bronce por el mismo escultor siete años antes, y colocada sobre un elevado pedestal que acrecentaba la impresión de distanciamiento con respecto a la reina. Volvía a ser una obra de gran relevancia que, no obstante, fue criticada en publicaciones como El Mundo Pintoresco, que consideraba un desdoro para los artistas españoles que se le hubiera encargado a un extranjero. "El parecido no es grande en verdad", afirmaba el autor de un texto anónimo publicado el 13 de junio de 1858, "el aire español, ese aire que en tan alto grado posee S. M. la Reina, tambien le falta en el monumento", aunque reconocía que "los demás detalles artísticos son de mucho mérito; la actitud magestuosa y digna, y los ropajes de mano maestra" ${ }^{22}$. La importancia de esta estatua era lo que más le hacía lamentarse de que "obras como el monumento en cuestion se encomienden á manos estranjeras, que si saben cincelar, no saben cómo circula en las venas la ardiente sangre española" ${ }^{23}$.

Como podemos comprobar, el auténtico valor que la sociedad isabelina concedía a esta clase de monumentos no estribaba solamente en el prestigio con el que contaban los personajes representados, sino también en la vinculación que el pueblo podía esta-

${ }^{21}$ E. TAMARIT, Op.cit.

22 "Estatua de Isabel II, en la Habana", El Mundo Pintoresco, nº 10, 13 de junio de 1858, p. 75.

${ }^{23}$ Ibídem. 
blecer con ellos, convirtiéndose el artista en un intermediario entre estos grandes monarcas, tanto del pasado como del presente, y la sociedad a la que debían servir como inspiración.

\section{LAS ESCULTURAS CONMEMORATI- VAS DE PERSONAJES HISTÓRICOS}

En estrecha relación con las representaciones de la monarquía se encontrarían las de personajes históricos de incuestionable trascendencia dentro de la historia del país. A pesar de que muchos pertenecieran a las capas más elevadas de la sociedad, lo que en el fondo les permitió en su momento gozar del estatus necesario para realizar las mismas hazañas por las que pasaron a la posteridad, la principal diferencia con respecto a los reyes era que su relevancia histórica no les había sido concedida al nacer, sino que se la habían ganado por sus propios méritos. En este caso, servirían mejor como referentes morales de cara a la sociedad isabelina, que los veía como auténticos compendios de virtudes militares o políticas en las que inspirarse. Al igual que las esculturas de Juana de Arco o Napoleón en Francia ${ }^{24}$, lord Palmerston en Inglaterra ${ }^{25}$, Godofredo de Bouillón en Bélgica ${ }^{26}$, Garibaldi o Gazzoletti en Italia ${ }^{27}$ y Abraham Lincoln en Estados Unidos ${ }^{28}$, España también contaba con numerosos monumentos conmemorativos de sus más

24 "Monumentos franceses. La estatua de Juana d'Arc", Semanario Pintoresco Español, tomo III, no 21, 25 de mayo de 1845 , pp. $165-166$ y "Estatua de Napoleon", Semanario Pintoresco Español, tomo III, nº 110, 6 de mayo de 1838, pp. 551-553.

25 "Crónica general", La Revista de Bellas Artes, tomo I, no 6, 11 de noviembre de 1866, p. 47 y "Crónica gene-

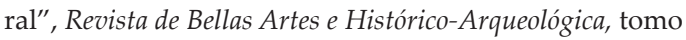
III, nº 66, 21 de enero de 1868, p. 239.

26 "Estátua de Godofredo de Bouillon erigida en la Plaza Real de Bruselas", Semanario Pintoresco Español, no 38, 23 de septiembre de 1851, p. 297.

27 "Correspondencia artística de Italia", La Revista de Bellas Artes, tomo I, no 43, 31 de julio de 1867, p. 350.

${ }^{28}$ BENISIA, "Artes y arqueología", La Revista de Bellas Artes, tomo I, nº 24, 17 de marzo de 1867, p. 191. conocidos personajes históricos, de lo cual daba buena cuenta la prensa de la época.

Sirvan como ejemplo las noticias sobre el proceso de realización de esculturas de don Diego López de Haro ${ }^{29}$ o de los comuneros de Castilla ${ }^{30}$, con cuyas biografías los españoles de mediados del siglo XIX estaban familiarizados por la difusión que los libros de historia realizaban de sus proezas incluso en la escuela. La repetición de estos temas permitió que la sociedad los asimilara, configurando poco a poco unas fisonomías reconocibles, sirviéndose tanto de retratos de la época como de elementos iconográficos que permitieran su inmediata identificación. Uno de los mejores exponentes de esto es, probablemente, Cristóbal Colón, del que Reyero sostiene que fue, junto con Cervantes, el personaje histórico más representado en la escultura, siempre con su característica melena, su frente despejada, su jubón con una sobrepelliz o un abrigo y su famoso gesto señalando hacia América con el índice ${ }^{31}$. En el caso que nos ocupa, no podemos estar más de acuerdo con él: Colón es el auténtico protagonista de los artículos publicados en la prensa isabelina sobre esta clase de representaciones, aunque, como veremos, el modo en que se abordó la realización de estos monumentos difería bastante de un caso a otro.

En El Mundo Pintoresco del 16 de diciembre de 1860 encontramos un poema de Francisca Carlota del Riego que coincide punto por punto con lo que acabamos de decir. Dedicado a José Piquer después de la erección en el pueblo cubano de Cárdenas de una escultura de Colón que acababa de rea$\operatorname{lizar}^{32}$, pone de manifiesto cómo la fisonomía

29 "Estatua de Don Diego López de Haro, Señor de Vizcaya", Semanario Pintoresco Español, nº 39, 30 de septiembre de 1855, p. 308.

30 "Academia de Nobles Artes de San Fernando", La Revista de Bellas Artes, tomo I, nº 25, 24 de marzo de 1867, p. 198.

${ }^{31}$ C. REYERO, Op. cit., pp. 145-146.

${ }^{32}$ J. E. GARCÍA MELERO, Arte español de la Ilustración y del siglo XIX: En torno a la imagen del pasado, Ma- 
del marino genovés se había vuelto tan reconocible que por aquel entonces no había una sola persona que fuera incapaz de identificarlo. Concretamente declaraba en una estrofa:

“Con tal verdad, primor y valentía El cincel de Piquer la ha dibujado Que es cosa inútil revelar su nombre, El inesperto niño,

El campesino menos ilustrado ¡Colon! dirán al verla, este es el hombre A quien la patria mía,

Debe un mundo ignorado

Que en lejanas regiones se escondía" ${ }^{\prime 33}$.

Igualmente interesantes, aunque en este caso por lo irrealizable del proyecto, son las menciones de la prensa a un colosal grupo escultórico de José Marín Baldo y Cachia del que se habló en diversas publicaciones. El primero en hacerlo fue una vez más El Mundo Pintoresco, que en su ejemplar del 6 de febrero de 1859 incluía un extenso artículo en el que reproducía la explicación que el artista les había dado a los redactores, cuando acudieron a visitarle interesados en su proyecto. Parece ser que lo ambicioso del mismo, realmente colosal en sus proporciones, no permitía que el Gobierno se hiciera cargo de "la suma de ochenta millones" que se necesitaría para su realización, lo que en opinión del autor del artículo era una auténtica lástima, puesto que "su conjunto nos parece elegante, esbelto y bello", además de que "su audacia y su grandeza asombran en verdad"34. Dicho conjunto, según la descripción del autor, se colocaría en el centro de una nueva plaza bautizada como la Plaza de

drid, $\overline{1998, \text { p. }} 319$

${ }^{33}$ F. C. DEL RIEGO PICA, "Al eminente escultor D. José Piquer, por su bellísima estátua de Cristóbal Colón", El Mundo Pintoresco, tomo III, no 1 , 16 de diciembre de 1860, p. 403. Sobre esta misma escultura El Mundo Pintoresco publicó una estampa una semana más tarde acompañando a un artículo de VARELA, “Estátua de Cristóbal Colon, hecha por el escultor de cámara señor Piquer, para el pueblo de Cárdenas en la isla de Cuba", El Mundo Pintoresco, tomo III, nº 52, 23 de diciembre de 1860, p. 413.

${ }^{34}$ V. B., "Monumento á Cristóbal Colón”, El Mundo Pintoresco, tomo II, no 6, 6 de febrero de 1859, pp. 43-44.
América; tendría un basamento cuadrado sobre el que se levantaría una apoteosis de Europa y en ella otra de España, un Museo Americano destinado a albergar los principales exponentes animales, vegetales y minerales del Nuevo Mundo, y una nueva apoteosis, en este caso de Colón, rematando la construcción ${ }^{35}$. Aunque irrealizable desde un punto de vista económico, el proyecto en sí mismo le granjeó una notable fama a Marín Baldo; por ejemplo, según El Arte en España, el hecho de que no pasara de ser una fantasía arquitectónica no impedía "que su autor sea un verdadero artista, que ha traducido su ideal de belleza en una concepcion grandiosa, noble y atrevida", lo que demostraba a todas luces que "en España no falta genio, inspiracion y talento á los artistas"36. Del mismo modo, La Revista de Bellas Artes del 18 de noviembre de 1866 se hacía eco de cómo Marín Baldo había realizado, en colaboración con los escultores Bellver y Rosado, un modelo del monumento, como es lógico de menor escala, que se quería presentar en la Exposición Universal de París ${ }^{37}$.

Igualmente desmesurado resultaba otro proyecto concebido por José de Manjarrés sobre el cual redactó una descripción publicada en 1863 en El Arte en España. También se trataba de un monumento a Colón,

${ }^{35}$ Ibídem. Años más tarde Marín Baldo, siempre con la idea de que algún día pudiera realizarse el monumento que diseñó, publicó una pormenorizada descripción del mismo en la que pasaba revista a la concepción de cada uno de estos elementos: J. MARÍN BALDO Y CACHIA, Proyecto de un monumento a la gloria de Cristóbal Colón y de España por el descubrimiento del Nuevo Mundo. Memoria, Madrid, 1876.

36 "Variedades", El Arte, nº 11, 16 de diciembre de 1866, p. 8.

37 "Crónica general", La Revista de Bellas Artes, tomo I, no 7, 18 de noviembre de 1866, p. 56. La información proporcionada por este artículo es desmentida por lo que sabemos que sucedió en realidad con dicho modelo; en lugar de enviarse a la Exposición Universal de París de 1867 se hizo a la de Filadelfia de 1876, en la que fue valorado muy positivamente y distinguido con una medalla de oro. J. L. MELENDRERAS GIMENO, "Iconografía colombina en Murcia durante el siglo XIX", Anales de Historia Contemporánea, nº 8, 1990-1991, p. 270. 
ideado en este caso para ser erigido en el Estrecho de Gibraltar. Las proporciones colosales de esta obra, de haber sido realizada, la habrían vuelto a acercar a ciertos modelos de la arquitectura utópica diseñados en Francia por Boullée y Ledoux ${ }^{38}$, una concepción nuevamente ambiciosa y excesiva que, como es evidente, no se acabaría llevando a cabo nunca. Veamos cómo había concebido el artista este monumento, y cuál era el significado de los elementos iconográficos que incorporaba:

"He creído que no convienen á semejante estátua dimensiones comunes, porque la idea del monumento decaería. Por esto las he concebido colosales; y he dado al monumento cincuenta metros de altura.

La estátua y el pedestal en que se apoya, deberán ser de bronce, así como las letras de la faja que rodea el globo. Esta esfera puede ser de piedra natural ó artificial, etc., etc.

La cabeza de la estátua ha de ser un observatorio; sirviendo para llegar á aquel punto, una escalera ó rampa practicada en la parte exterior de la esfera, por encima de la faja que la rodea; yendo á parar al pié de la fachada posterior del pedestal; y siguiendo por el interior del mismo y del brazo izquierdo de la estátua.

La figura se apoya en el pedestal, teniendo este en su fachada anterior el escudo de armas de los Reyes Católicos; en la lateral los atributos de estos monarcas; y en la posterior la dedicatoria, fecha, etc., etc.

Con el ademan de la estátua se ha querido sancionar el significado del mote escrito en la faja que rodea la esfera.

En cualquier otro punto que no sea el estrecho de Colon (ya no de Gebal-Tarils),

\footnotetext{
${ }^{38}$ Tanto el proyecto de Marín Baldo como el de Manjarrés incorporaban grandes estructuras esféricas que recuerdan al cenotafio diseñado por Boullée para Isaac Newton en 1784, además de a otras famosas construcciones cuya perdurabilidad se pretendía imitar, como por ejemplo el Panteón de Agripa en Roma o la cúpula de la Catedral de San Pablo de Londres. P. NAVASCUÉS PALACIO, "El problema del eclecticismo en la Arquitectura Española del s. XIX", Revista de ideas estéticas, nº 114, 1971, p. 71. Cfr. en J. L. MELENDRERAS GIMENO, Op.cit..
}

el monumento carecerá de conveniencia de localidad: de menores dimensiones que las propuestas, no será proporcionado á la grandeza de la empresa. Por último, es preciso que los navegantes al pasar el Estrecho, vean aquella mano, asi de dia proyectándose por oscuro sobre el azul del cielo, como de noche presentándose en silueta sobre el cielo estrellado, diciéndole: PODEIS IR MÁS ALLÁ"39.

"Se me alcanza muy bien", reconocía José de Manjarrés, "que la realizacion de este proyecto ha de hallar contradicciones de toda clase y de todo género", algo que no parecía importarle puesto que, como seguía diciendo, "Colon las halló para llevar á cabo la empresa; y la buena voluntad de la reina de Castilla Isabel I las venció todas" ${ }^{\prime 40}$. En el fondo, no era más que una manera de apelar a Isabel II para que demostrase apoyando este proyecto que era digna heredera de su antepasada, un mecanismo de identificación de lo más recurrente en España durante su reinado, y que explica la gran proliferación de obras de arte dedicadas a ensalzar a la Reina Católica que se estaban creando por entonces.

Es curioso que, pese al indudable interés que despertaba la figura de Colón entre los españoles de mediados del siglo XIX, hubiera que esperar tanto tiempo a que fuera erigido un monumento en su honor. Con la excepción de la escultura de Cárdenas, todas las menciones aparecidas en la prensa a las que hemos pasado revista remitían a diseños irrealizables, y precisamente por eso abundaban las voces que pedían que se emprendiera de una vez un proyecto más abordable dedicado al genovés. La Revista de Bellas Artes e Histórico-Arqueológica, por ejemplo, hacía este llamamiento en su ejemplar del 14 de enero de 1868, apelando a una suscripción pública ${ }^{41}$; y algo similar hacía tam-

${ }^{39}$ J. DE MANJARRÉS, "Proyecto de un monumento á Cristóbal Colón”, El Arte en España, tomo II, 1863, pp. 121-123.

\footnotetext{
${ }^{40}$ Ibídem.

41 "Crónica general", Revista de Bellas Artes e HistóricoArqueológica, tomo III, nº 65, 14 de enero de 1868, p. 224.
} 
bién con otro proyecto de monumento a los Conquistadores de América (Colón, Cortés y Pizarro) que se pretendía colocar en una plaza del mismo nombre construida en torno a la Puerta de Alcalá, proyecto que sabemos que tampoco se realizó ${ }^{42}$. Solo cuando Isabel II había sido derrocada comenzamos a encontrarnos con las primeras esculturas de Colón, como la de Rafael Atché en Barcelona (de 1888), las de Eduardo Barrón en Salamanca (Fig. 1), Jerónimo Suñol y Arturo Mélida en Madrid, Mariano Benlliure en Granada y Paolo Triscornia di Ferdinando en Las Palmas de Gran Canaria (las cuatro de 1892, coincidiendo con el cuarto centenario del descubrimiento de América), la de Antonio Susillo en Valladolid (de 1905) y la de Juan Martín y Serra en Cartagena (de 1921) ${ }^{43}$.

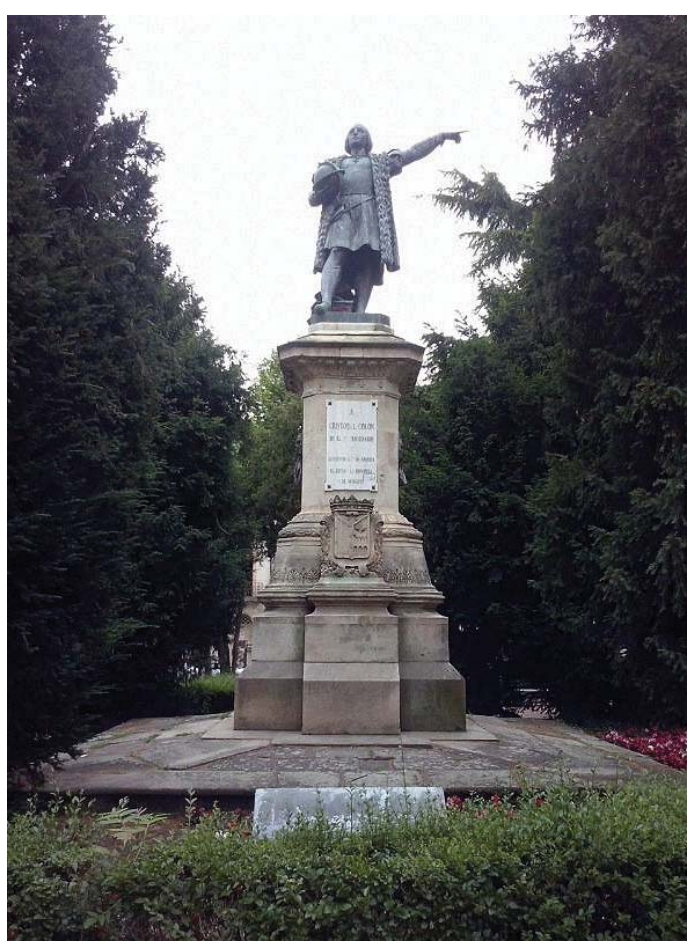

- Fig. 1. Monumento conmemorativo de Cristóbal Colón en Salamanca. Eduardo Barrón. 1892. Fotografía de la autora.

42 Nota aparecida en La Revista de Bellas Artes, tomo I, no 16, 20 de enero de 1867, p. 123 y "Más sobre la erección de un monumento á Colón, Cortés y Pizarro", $\mathrm{La}$ Revista de Bellas Artes, tomo I, nº 17, 26 de enero de 1867, pp. 134-136.

${ }^{43}$ C. REYERO, Op. cit., pp. 145-147.
Todas estas obras solían coincidir en su tipología: monumentos de una sola estatua situada en lo alto de un elevadísimo pedestal, un paralelepípedo de sección normalmente cuadrada que establecía un punto de vista frontal del representado, mientras que los laterales solían contar con relieves, escudos o alegorías. Esta clase de pedestales, que por su altura podríamos denominar columnarios, dificultaban notablemente la percepción de la estatua propiamente dicha, pero al mismo tiempo aumentaban la teatralidad del conjunto. Y a pesar de que su concepción no fuera la misma, es evidente que todos estos diseños recogían el testigo de los que habían sido ideados décadas antes. La fascinación por Colón no había hecho más que crecer desde entonces, y a finales de la centuria su fisonomía había sido tan asimilada por parte de la sociedad que el reconocimiento de su apariencia física resultaba inmediato a pesar de la distancia a la que se encontrara ${ }^{44}$.

\section{LAS ESCULTURAS CONMEMORATI- VAS DE HÉROES DE LA PATRIA}

También de carácter histórico, aunque representaran a un colectivo en vez de a un personaje concreto, eran los monumentos erigidos en honor a grupos de individuos que encarnaban las virtudes del patriotismo. Solían tener relación con episodios de carácter militar acaecidos en el país, aunque no necesariamente hubieran sido venturosos para los españoles; en este sentido, nos encontramos a menudo con un interesante culto a los caídos en el que el pueblo contaba con una importancia incuestionable. De nuevo no se trata de una excepción; también en Europa se habían emprendido proyectos similares en las mismas fechas, como demuestran las menciones aparecidas en la prensa artística a monumentos erigidos en campos de batalla como Champaubert, Montmirail,

${ }^{44}$ Sobre este tema, que excede el ámbito cronológico de nuestro estudio, recomendamos el interesante análisis de J. L. DÍEZ, "Iconografía colombiana en España entre los siglos XIX y XX" en P. BOCCARDO, J. L. COLOMER y C. DI FABIO (coords.), España y Génova. Obras, artistas y coleccionistas, Madrid, 2004, pp. 247-258. 
Château-Thierry y Vauchamps en Francia ${ }^{45}$, Monterotondo en Italia ${ }^{46}$ o Scheverin en Sui$\mathrm{za}^{47}$. En el caso español, los ejemplos más notables corresponden a episodios de la Guerra de la Independencia, cercanos por tanto en el tiempo; y entre ellos, el levantamiento del Dos de Mayo de 1808 constituía un referente tan asimilado por los españoles como el de Colón.

Al igual que sucedía con otras representaciones, como los Sitios de Zaragoza que también inspiraron a escultores del siglo $\mathrm{XIX}^{48}$, los artistas que se ocuparon de este tema optaron por mostrar el carácter heroico de los combatientes españoles a través de su sufrimiento. Lejos quedan las imágenes grandilocuentes y gloriosas de los monarcas de los que hemos hablado antes; lo que hacía que estos monumentos calaran hondo en la sociedad isabelina era la idea de sacrificio, de dignidad en la derrota, de plantar cara al enemigo, en este caso los soldados napoleónicos, demostrando que el tópico acuñado en Europa sobre la fiereza de los españoles era algo más que palabrería.

Evidentemente, el ejemplo más representativo de esto es el monumento a los Héroes del Dos de Mayo erigido en 1840 en la madrileña Plaza de la Lealtad, en el mismo

${ }^{45}$ BENISIA, "Artes y arqueología", La Revista de Bellas Artes, tomo I, no 24, 17 de marzo de 1867, p. 191.

46 "Crónica general", Revista de Bellas Artes e Histórico-Arqueológica, tomo III, no 66, 21 de enero de 1868, p. 240.

47 "Inauguración del monumento guerrero de Scheverin", Semanario Pintoresco Español, no 52, 25 de diciembre de 1853, p. 409.

${ }^{48}$ Destaca especialmente en ese sentido el famoso grupo de la Defensa de Zaragoza expuesto en el Museo del Prado que el escultor José Álvarez realizó en 1818. Desde el momento de su realización fue una obra muy admirada por los españoles, como dejan constancia algunos artículos aparecidos en la prensa artística como J. AMADOR DE LOS RÍOS, “Biografía. D. José Álvarez, célebre escultor contemporáneo", El Laberinto, tomo I, no 20, 16 de agosto de 1844 , pp. 267-269 y "Real Museo de Escultura. Grupo llamado de Zaragoza, de Álvarez", Semanario Pintoresco Español, tomo I, no 23, 7 de junio de 1846, p. 183. lugar en que el general Murat había mandado fusilar a numerosos ciudadanos después del levantamiento. Sus cenizas reposan según la tradición en un sarcófago colocado en la base cuadrada de este gran grupo escultórico, sobre el que puede observarse un medallón con un bajorrelieve de los capitanes Daoíz y Velarde rematado por otro cuerpo, de menores dimensiones y sección octogonal, con cuatro grandes alegorías de la Constancia, la Virtud, el Valor y el Patriotismo. Sobre todo esto, un obelisco de más de cinco metros de altura con la inscripción DOS DE $M A Y O$ en su frente convierte al monumento en uno de los hitos del urbanismo madrileño. En cuanto a los artistas que participaron en este proyecto, cabe mencionar el nombre de su arquitecto, Isidro González Velázquez, así como los de los escultores que colaboraron con él, como Esteban de Agreda, José Tomás, Francisco Elías Vallejo, Francisco Pérez del Valle, Sabino Medina y Diego Hermoso ${ }^{49}$.

Curiosamente, la atención prestada por la prensa artística a este monumento no es tan grande como la que se dedicaba a los que hemos visto hasta ahora. Esto no quiere decir que la obra no les pareciera meritoria a sus redactores, sino que su trascendencia patriótica había alcanzado unas cotas tan altas que, cuando se hablaba de ella, siempre se acababa dedicando más espacio a la narración de los sucesos históricos del Dos de Mayo que al monumento propiamente dicho. Es lo que ocurre con los artículos aparecidos en El Mundo Pintoresco el 2 de mayo de 1858 y el 6 de mayo de 1860, coincidiendo con el aniversario del levantamiento, en los que se ensalzaba el arrojo de aquellos madrileños y se animaba a sus descendientes a rendirles homenaje acudiendo a visitar la obra como si de un peregrinaje anual se tratara ${ }^{50}$. Algo similar sucedía con un extenso texto, también de carácter histórico, que vio

${ }^{49}$ C. REYERO, Op. cit., p. 503.

${ }^{50}$ F. UTRERA, "El dos de mayo", El Mundo Pintoresco, no 4, 2 de mayo de 1858, pp. 25-26 y 29 y "El 2 de mayo", El Mundo Pintoresco, tomo III, no 19, 6 de mayo de 1860 , pp. $49-50$. 
la luz en El Laberinto el 1 de mayo de 1844, encabezado por una estampa del monumento que demuestra cómo se había convertido por entonces en todo un símbolo para la nación. Iba acompañado por un soneto de Gertrudis Gómez de Avellaneda que, en este caso sí, se encontraba dedicado a la obra. Decía lo siguiente:

"Mármol que guardas inmortal memoria

De alta constancia, de virtud severa,

Yo te saludo por la vez primera,

Ardiendo en sed de libertad, de gloria!

La página mas bella de su historia

Grabó en tu frente la nacion Ibera,

Y en ti verá la gente venidera

De un pueblo heróico la mayor victoria.

¡Oh, no te admire el universo en vano!

De la ambicion el ímpetu sañudo

Québre en tu base su furor insano;

Y háble á los pueblos tu silencio mudo,

Y háble tambien al opresor tirano....

¡Monumento inmortal! yo te saludo"51.

Pese a la indudable admiración que manifiestan estos versos, echamos en falta un análisis más pormenorizado de este monumento, sobre todo teniendo en cuenta que la trascendencia que se le había concedido lo situaba muy por encima de otras iniciativas escultóricas a las que sin embargo se prestaba mayor atención. Probablemente se debiera a lo que acabamos de mencionar: el episodio del Dos de Mayo era tan conocido entre los españoles que a los redactores de estas revistas debía de parecerles innecesario detenerse en su iconografía, un claro ejemplo de cómo la asimilación del mensaje por parte de la sociedad había tenido tanto éxito que el monumento había dejado de ser una creación artística para convertirse en un auténtico emblema del nacionalismo español.

${ }^{51}$ G. GÓMEZ DE AVELLANEDA, "Al monumento del Dos de Mayo. Soneto", El Laberinto, tomo I, no 13, 1 de mayo de 1844, p. 180.

\section{LAS ESCULTURAS CONMEMORATI- VAS DE PERSONALIDADES DE LA IGLESIA}

Esta categoría, aunque más somera que las anteriores, nos parece de gran interés porque demuestra, más claramente que ninguna otra, cómo en la España del siglo XIX se estaba llevando a cabo un proceso de secularización extensivo al ámbito de las Bellas Artes. En efecto, casi toda la escultura pública que encontrábamos en nuestro país antes de esta centuria era de carácter religioso, algo que, en la era contemporánea, cambió por completo, relegando dichas imágenes a los templos. En opinión de Reyero, se trata de un fenómeno que pone de manifiesto los esfuerzos del Estado moderno por apropiarse de los espacios públicos, pese a lo cual seguimos encontrando algunos exponentes aislados que muestran cómo los personajes religiosos no habían abandonado aún sus pedestales ${ }^{52}$.

La Inmaculada Concepción, por ejemplo, continuaba estando muy presente en la religiosidad española de la época isabelina, y su presencia era una constante en la vía pública de las ciudades. En la prensa artística encontramos numerosas menciones a la construcción de monumentos dedicados a este dogma, tanto en el extranjero ${ }^{53}$ como en nuestro propio país ${ }^{54}$. Algo parecido sucedería con algunos santos como San Carlos Borromeo, del que se había construido una colosal estatua en la localidad milanesa de Arona, en la que nació, que aún seguía susci-

${ }^{52}$ C. REYERO, Op. cit., p. 399.

${ }^{53}$ V. B., "Inauguración en Roma de la estatua de la Concepción", El Mundo Pintoresco, no 24, 19 de septiembre de 1858, pp. 185-187.

${ }^{54}$ FIDELIO, "Suplemento del Mundo Pintoresco. Boletín de noticias", El Mundo Pintoresco, tomo II, no 11, 13 de marzo de 1859, sin página. ÍDEM, "Suplemento del Mundo Pintoresco. Boletín de noticias", El Mundo Pintoresco, tomo II, no 41, 9 de octubre de 1859, sin página y SIERRA, "La Concepción. Escultura colocada sobre la puerta de los Leones de la catedral de Toledo", El Mundo Pintoresco, tomo III, no 32, 5 de agosto de 1860, p. 256. 
tando admiración ${ }^{55}$, o San José de Calasanz, honrado con otra estatua colocada en 1867 en la Casa de Beneficencia de Valencia ${ }^{56}$. No obstante, existe una diferencia fundamental entre estos monumentos religiosos y los que se habían construido en los siglos anteriores, y es que lo que realmente convertía a los representados en modelos de inspiración a los ojos de la sociedad isabelina no eran sus virtudes religiosas, sino más bien las morales. Los hombres santos pasaban a ser, por lo tanto, ciudadanos perfectos que los españoles del siglo XIX debían aspirar a imitar, en un mecanismo de adaptación a los nuevos tiempos que no dejara de lado la religiosi$\operatorname{dad}^{57}$.

Lo mismo sucedería con los monumentos dedicados a hombres de la Iglesia que también eran considerados merecedores de admiración. En este sentido, el que más atrajo la atención fue el erigido en honor a Fray Luis de León en Salamanca, delante de la fachada de la universidad, en abril de 1868 (Fig. 2). Había sido realizado por el escultor Nicasio Sevilla durante una estancia en Roma, ganando el premio convocado a este respecto por la Real Academia de Bellas Artes de San Fernando ${ }^{58}$. En este caso nos encontramos con una tipología mucho más sencilla que la del monumento dedicado a los Héroes del Dos de Mayo: sobre un paralelepípedo de mármol, decorado en sus caras laterales con dos alegorías femeninas de la poesía sagrada y la poesía profana, se yergue la estatua fundida en bronce, en pie y ligeramente vuelta hacia un lado como si estuviera impartiendo una clase al tiempo que establece una comunicación con el observador mediante el elocuente gesto de su mano derecha.

55 "Estatua colosal de San Carlos Borromeo", Semanario Pintoresco Español, tomo III, no 127, 2 de septiembre de 1838, pp. 693-694.

56 "Crónica general", Revista de Bellas Artes e Histórico-Arqueológica, tomo II, nº 58, 21 de noviembre de 1867, p. 112.

${ }^{57}$ C. REYERO, Op.cit..

58 J. BELDA PLANS, Grandes personajes del Siglo de Oro español, Madrid, 2013, p. 242.

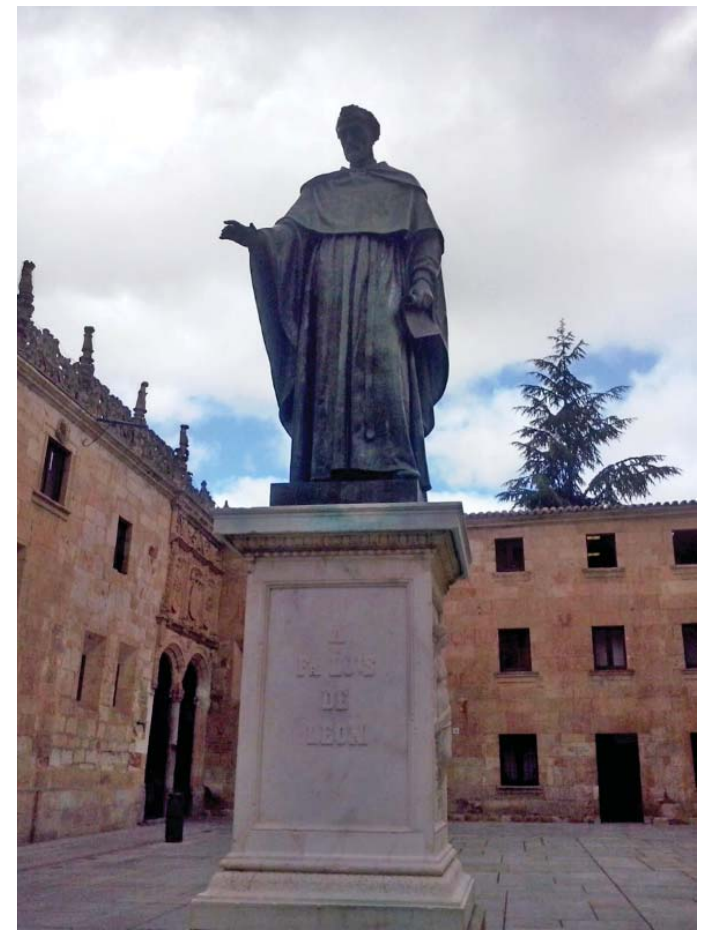

- Fig. 2. Monumento conmemorativo de Fray Luis de León en Salamanca. Nicasio Sevilla. 1868. Fotografía de la autora.

Dos años antes de la inauguración de esta obra en Salamanca encontramos las primeras menciones al proyecto en la prensa artística. En La Revista de Bellas Artes del 18 de noviembre de 1866 se incluyó un artículo redactado por J. Mesa y Leompart en el que explicaba cómo el artista había querido retratar a Fray Luis de León:

“La actitud de la estátua es natural y tranquila, como conviene al grave y sencillo discurso del maestro de letras. El Sr. Sevilla, huyendo de la exageracion á que sin duda le habria conducido el intento de representar la exaltacion del orador sagrado, ha tenido el buen juicio de tomar al eminente literato y poeta en el ejercicio de la más noble de las profesiones: la enseñanza; le ha representado en medio de sus queridos discípulos, olvidándose entre ellos de todas las amarguras de la vida. Decíamos ayer:... esta sublime expresion de una virtud rarísima en aquel siglo, la tolerancia, ha servido de tema á la concepcion del artista, que en su realizacion ha estado felicísimo: la calma, la dulzura, 
la tranquilidad del sábio se hallan perfectamente expresadas en la actitud y en la fisonomía de la estátua. La cabeza está algo inclinada, en señal de bondadosa indulgencia. Los pliegues del ropaje forman grandes masas; á fin de que, heridos más de lleno por la luz, produzcan mejor efecto" ${ }^{\prime 2}$.

En opinión de Mesa y Leompart, uno de los aspectos más destacables de esta estatua era que se trataba de una de esas obras "que representan la verdad y ensalzan al génio", distinguiéndose de otras semejantes de carácter religioso que, "inspiradas al parecer en un exaltado misticismo, no están en armonía con las tendencias generales del arte moderno" ${ }^{\prime 60}$. Es interesante esta matización porque nos permite comprender hasta qué punto los monumentos conmemorativos de la segunda mitad del siglo XIX habían evolucionado en cuanto a su concepción; por entonces habían dejado de centrarse en el afán por ensalzar al representado para plasmarlo con una mayor naturalidad, acercando su imagen a la sociedad mediante un mecanismo de identificación mucho más moderno.

La misma admiración por esta estatua puede percibirse en los demás artículos que La Revista de Bellas Artes dedicó a su inauguración, como una nota publicada el 14 de enero de 1868 en la que se anunciaba que, con motivo de la fiesta celebrada en su honor los días 25, 26 y 27 de abril ${ }^{61}$, el rector apelaba “á varios de nuestros más notables literatos, para que hagan composiciones alusivas al objeto, con las cuales se formará un libro" ${ }^{\prime 2}$. En dicha nota se añadía, además, que la estatua había sido realizada en Roma y se pretendía fundirla en bronce

\footnotetext{
${ }^{59}$ J. MESA Y LEOMPART, “Real Academia de San Fernando. Monumento á Fray Luis de León", La Revista de Bellas Artes, tomo I, no 7, 18 de noviembre de 1866, p. 55.

${ }^{60}$ Ibídem.

${ }^{61}$ C. REYERO, Op. cit., p. 468.

62 "Crónica general", Revista de Bellas Artes e Histórico-Arqueológica, tomo III, no 65, 14 de enero de 1868, p. 224.
}

en Marsella ${ }^{63}$, mientras que, en otro artículo publicado el 5 de abril, se decía de ella, ya acabada, que era colosal, y que antes de su traslado a Salamanca permanecería expuesta durante unos días en la Real Academia de Bellas Artes de San Fernando, para que acudieran a admirarla quienes estuvieran interesados ${ }^{64}$.

En la misma línea se encontraban las noticias relacionadas con otros monumentos como el dedicado a Fray Domingo de Silos Moreno, obispo de Cádiz, obra realizada por Leoncio Baglietto que comparte con la estatua de Fray Luis de León la naturalidad de la actitud; en ella el representado hace el gesto de bendecir con la mano derecha, mientras que, con la izquierda, presenta al pueblo gaditano el plano de la catedral que se encargó de concluir ${ }^{65}$. Vuelve a ser un monumento sacado a concurso, esta vez por la Academia de Bellas Artes de Cádiz, que, en palabras del autor de este artículo, había valorado muy positivamente que el boceto de Baglietto poseyera "dibujo correcto, grandes y regulares proporciones, ropas bien plegadas, natural acusado con inteligencia y economía, movimiento delicado, y filosofía en el momento elegido para representar a su héroe" ${ }^{\prime 66}$. Otras veces, la información proporcionada por estos artículos nos habla de proyectos que quedaron en suspenso, como el de la escultura del cardenal Belluga en Murcia, cuyos planos habían sido devueltos por el Gobierno a la municipalidad puesto que la Real Academia de Bellas Artes de San Fernando había decidido, una vez más, que lo más correcto sería sacar su realización a concurso $^{67}$. En este caso, hubo que esperar

$$
{ }^{63} \text { Ibídem. }
$$

${ }^{64}$ Ibídem, no 76, 5 de abril de 1868, p. 16

${ }^{65}$ C. SARTHOU CARRERES, Catedrales de España (su pasado y su presente), Barcelona, 1946, p. 97.

66 "Estatua del difunto obispo de Cádiz, por D. Leoncio Baglietto", Semanario Pintoresco Español, no 15 , 15 de abril de 1855 , p. 118.

67 "Crónica general", Revista de Bellas Artes e Histórico-Arqueológica, tomo III, nº 66, 21 de enero de 1868, p. 239. 
casi un siglo para que Murcia contara con este monumento en la plaza que llevaba su nombre, ya que la escultura del cardenal, realizada finalmente por Juan González Moreno, no fue inaugurada hasta 1958, doscientos quince años después de la muerte del representado ${ }^{68}$.

\section{LAS ESCULTURAS CONMEMORATI- VAS DE PERSONALIDADES DE LA CULTURA}

En último lugar, aunque no por ello resulten menos importantes, se encontrarían las esculturas conmemorativas de personajes eminentes pertenecientes a los diferentes campos de la cultura, que para la sociedad española del siglo XIX resultaban también unos modelos dignos de la mayor admiración. Como hemos visto que solía suceder en los casos anteriores, la prensa de la época isabelina recogió numerosas noticias acerca de los monumentos dedicados a las grandes glorias extranjeras. Algunas despuntaron en el ámbito de la literatura como Shakespeare $^{69}$, Goethe o Schiller ${ }^{70}$, otras lo hicieron en el de la filosofía como Voltaire ${ }^{71}$, Montesquieu $^{72}$, Montaigne ${ }^{73}$ o Fenelon ${ }^{74}$, otras en el de la música como Haydn ${ }^{75}$ o Beethoven ${ }^{76}$,

${ }^{68}$ J. E. RUBIO ROMÁN, "De cómo el Cardenal Belluga tuvo estatua en Murcia tras 75 años de dimes y diretes", La Opinión de Murcia (en línea), 16 de noviembre de 2010, consultado el 30 de abril de 2014. URL: http://www.laopiniondemurcia.es/murcia/2010/11/16/ cardenal-belluga-tuvo-estatua-murcia-75-anos-dimesdiretes/283712.html

69 “Variedades", El Artista, tomo II, nº 10, 1835, p. 119.

${ }^{70}$ V. CUENCA DE LUCHERINI, "Goethe y Schiller", El Mundo Pintoresco, no 2, 18 de abril de 1858, p. 12.

71 "Artes y arqueología", La Revista de Bellas Artes, tomo I, no 43, 31 de julio de 1867, p. 352.

72 "Variedades", El Artista, tomo II, no 10, 1835, p. 120.

${ }^{73}$ Ibídem, p. 120 y no 19,1835 , p. 228.

${ }^{74}$ Ibídem, no 19,1835 , p. 228

75 "Crónica general", La Revista de Bellas Artes, tomo I, no 10,9 de diciembre de 1866, p. 80 .

76 "Variedades", El Artista, tomo II, no 19, 1835, p. 228 y "Revista del mes de agosto. Estrangero", El Siglo otras en el de la pintura como Poussin ${ }^{77} \mathrm{o}$ Ingres $^{78} \mathrm{y}$ otras se ganaron los laureles de la fama mediante sus invenciones, como $\mathrm{Gu}$ tenberg ${ }^{79}$. El caso español no fue una excepción, aunque las menciones aparecidas en la prensa solían limitarse a escritores y pintores, destacando entre ellos a los dos que habían pasado a encarnar con el paso del tiempo la esencia de la españolidad: Cervantes y Velázquez.

Es cierto que también se publicaron unas cuantas menciones a esculturas de otros literatos de incuestionable relevancia, como la de Garcilaso de la Vega, colocada al lado de la de su hijo en su sepulcro de San Pedro Mártir de Toledo, a pesar de que realmente no fuera un monumento conmemorativo sino funerario ${ }^{80}$. Pero la figura de Miguel de Cervantes Saavedra poseía una trascendencia que la hacía elevarse por encima de todas las demás, de lo que dan buena cuenta proyectos escultóricos como el de Antonio Solá que se puede admirar actualmente en la Plaza de las Cortes (Fig. 3). Aunque menos espectacular que el que se erigiría más tarde en la Plaza de España, atrajo desde el primer momento la atención tanto de los ciudadanos españoles como de los italianos, puesto que el artista realizó la escultura en bronce de Cervantes en Roma en colaboración con Jollage y Hopfgarten ${ }^{81}$.

Pintoresco, tomo I, nº 5, agosto de 1845 , p. 119.

77 "Estatua de Poussin”, Semanario Pintoresco Español, no 3, 19 de enero de 1851, p. 17 y "El célebre pintor Poussin (estátua en mármol por Julien)", El Mundo Pintoresco, tomo III, nº 23, 3 de junio de 1860, p. 177.

78 "Artes y arqueología", La Revista de Bellas Artes, tomo I, no 28, 14 de abril de 1867, p. 222.

79 "La estatua de Gutemberg", Semanario Pintoresco Español, tomo III, nº 30, 25 de julio de 1841, pp. 235-236.

80 "Estatua de Garcilaso de la Vega", Semanario Pintoresco Español, no 35, 1 de septiembre de 1850, p. 280.

${ }^{81}$ No en vano Antonio Solá, aunque oriundo de Barcelona, se había marchado a Roma a formarse como escultor y se había quedado a vivir allí, convirtiéndose en director de los pensionados españoles en esta ciudad. A. M. PRECKLER, Historia del arte universal de los siglos XIX y XX, tomo I, Madrid, 2003, p. 95. 
También se levanta sobre un paralelepípedo de mármol dispuesto a su vez sobre unas gradas, lo que aumenta su teatralidad pese a que, como explicaremos más adelante, en su momento se granjeara muchas y enconadas críticas por parte de la opinión pública que no se hicieron extensivas a la estatua. El pedestal cuenta con dos relieves realizados por José Piquer, uno con la escena de Don Quijote y Sancho Panza guiados por la Locura, y el otro con la aventura de los leones.

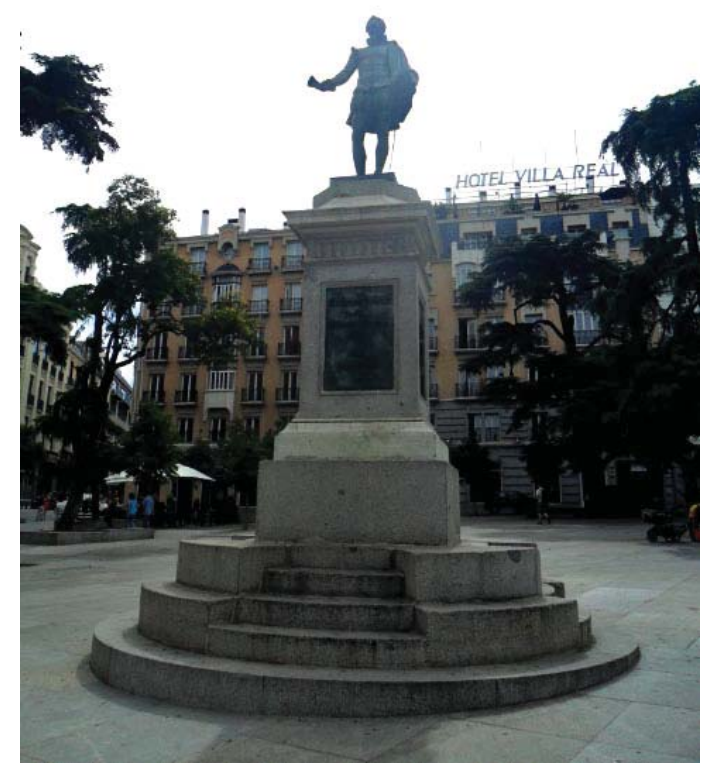

- Fig. 3. Monumento conmemorativo de Miguel de Cervantes en Madrid. Antonio Solá. 1835. Fotografía de la autora

La prensa artística no escatimó elogios respecto a esta obra; El Artista, por ejemplo, aseguraba que era "objeto de la admiracion de todos los inteligentes, no solo por el mérito de la escultura sino por el esquisito trabajo de la fundicion en bronce, la cual, nos aseguran testigos oculares, es un verdadero dechado en su género" ${ }^{\prime 2}$. Más información proporcionaba un artículo de autor desconocido del Semanario Pintoresco Español del 30 de octubre de 1836, en el que se señalaba

82 "Variedades", El Artista, tomo I, nº 9, 1835, p. 108. que "este testimonio de consideración pública tributado á Cervantes, es en nuestro pais único en su especie, y merecia muy bien abrir este honroso camino el hombre inmortal á quien la España debe su primer blason literario"$^{\prime 83}$. Además, aportaba una pormenorizada descripción de esta figura en pie, publicada por primera vez en italiano en el Diario de Roma y redactada por Salvador Betti, secretario de la academia romana de San Lucas. Como podemos comprobar, los italianos también la consideraban magnífica:

“Loor al señor de Solá el que con tanta verdad y perfeccion del arte nos hace ver la imagen de este famoso escritor. Le vemos en ella, es el mismo Miguel de Cervantes cual lo manifiesta aquella noble figura; su espaciosa frente, aquellos ojos llenos del fuego del alma, aquel andar franco tan natural al hombre de armas y de aventuras, y aquel aire en que se ven las maneras españolas del siglo XVI. Lleno de una sublime imaginacion está en actitud de mudar el paso: actitud que no podia con mas facilidad y maestría mostrarse por el artista, ya por el movimiento natural de las piernas la que acompaña el de toda la persona, ya por el contraste de los pliegues del vestido y especialmente de la capa que el aire mueve con suavidad. En la mano derecha tiene un lio de papeles, muestra de un literato: la izquierda la tiene sobre el puño de la espada en prueba de su profesion militar y nobleza de sus antepasados; y para ocultar la imperfección de esta mano á causa de una herida de arcabuz que en ella recibió en la batalla de Lepanto, Solá ha tenido la singular idea de cubrirla con un pliegue de la capa, conservando de este modo todo lo perfecto, sin esponerse á la censura de los que exigen la verdad" $" 84$.

Curiosamente, los españoles fueron más críticos que los italianos en cuanto a la semblanza de este Cervantes; aunque consideraran que la obra de Solá era de todo pun-

\footnotetext{
83 "Estatua de Cervantes", Semanario Pintoresco Español, tomo I, nº 31, 30 de octubre de 1836, p. 253.

${ }^{84}$ Ibídem, p. 250.
} 
to meritoria, algunos autores se quejaron en la prensa de que "la postura marcial, el trage militar, y hasta el papel que tiene en la mano presenta mas bien la idea de un guerrero", un defecto en su actitud teniendo en cuenta que la finalidad de esta escultura era alabar "al autor del Quijote aun mas bien que al manco de Lepanto y al cautivo de Argel"85. Se trataba de un detalle que, en opinión de estos críticos, impedía que la obra estuviera a la altura de monumentos como los dedicados a Shakespeare, a Erasmo, a Newton o a Rousseau $^{86}$, una censura que, evidentemente, tenía sentido viniendo del propio pueblo español, pero que para extranjeros como el signor Betti no quitaba méritos a esta obra:

"Todo es vida en esta estátua, todo vivacidad al mismo tiempo que se ve la dignidad. Y como intendente de las bellas artes digo, como sentencia universal, que esta estátua es una de las mas célebres que se han hecho en este siglo, y una de las mas importantes por ser del hombre tan grande que representa. Añadiré además que hace muchos años que no se ha fundido otra igual en bronce en este país, pues es semicolosal teniendo diez palmos y medio de altura" ${ }^{\prime 87}$.

Este artículo también hacía referencia al resto de elementos que completaban el monumento, como los dos relieves de José Piquer y el pedestal en cuyos laterales fueron colocados. Como hemos mencionado antes, este tema suscitó en su momento bastante polémica, porque el proyecto de pedestal original de Solá no fue aprobado por la Real Academia de Bellas Artes de San Fernando, sino que se encargó un segundo diseño a Isidro Velázquez que sería bastante criticado en la prensa. Principalmente, esto se debió a su elevada altura, que aunque podía ser adecuada en un monumento como los que hemos descrito anteriormente de Colón, no hacía más que entorpecer la contemplación de la efigie cervantina. También a la

\footnotetext{
${ }^{85}$ Ibídem, pp. 251-252.

${ }^{86}$ Ibídem, p. 251.

${ }^{87}$ Ibídem.
}

verja de hierro que en su momento rodeaba a esta obra, conocida popularmente por los madrileños de aquel entonces como "la jaula del jilguero", y que en época reciente ha sido eliminada, además de trasladar el conjunto entero a otra parte de la Plaza de las Cortes durante las obras de remodelación de 2009.

En El Artista, por ejemplo, aseguraban sobre esta cuestión del pedestal sentir que no se colocara la escultura sobre el elegante diseño original de Solá. "Y lo sentimos tanto mas", continuaba el autor de este artículo, "cuanto el que se está erigiendo [...] para aquel objeto nos parece pasablemente malo", dado que "el Sr. Solá calculó muy bien sus dimensiones, y es sabido que el efecto de una estátua depende en gran manera de la altura á que está colocada" ${ }^{\prime 8}$. Unas semanas más tarde, esta misma revista anunciaba que se estaba procediendo a colocar la escultura en su emplazamiento, "pero como aun no está terminado su pedestal, nos abstenemos de hablar de él por ahora"89. En Semanario Pintoresco Español, por su parte, se hicieron eco asimismo de estas críticas:

"Sobre su merito artístico tambien se ha hablado en diversos sentidos sin que nos hallemos en el caso de decidir absolutamente, y pareciéndonos tan solo extremada su altura. Tampoco nos gusta el verlo tan encerrado en la balaustrada de hierro que á nuestro entender le impide campear con gallardía, y menos aun la banal inscripcion,

\section{A MIGUEL DE CERVANTES}

SAAVEDRA

PRÍNCIPE DE LOS INGENIOS ESPAÑOLES

\section{AÑO}

DE M.D.CCC.XXXV"90.

\footnotetext{
88 "Variedades", El Artista, tomo II, no 1, 1835, p. 12.

${ }^{89}$ Nota aparecida en El Artista, tomo II, nº 8, 1835, p. 96.

90 "Estatua de Cervantes", Semanario Pintoresco Español, tomo I, nº 31, 30 de octubre de 1836, p. 252.
} 
En cuanto al artista español que se creía que había destacado más en el campo de la pintura, Diego Velázquez, también encontramos referencias dignas de interés en estas publicaciones, aunque sin alcanzar la importancia concedida a Cervantes. La España de Isabel II no dudó nunca en encumbrar al pintor sevillano al panteón de sus hijos más notables, pero en la época en la que nos ocupamos aún no se le había dedicado ningún monumento que pudiera competir con los que hasta ahora hemos mencionado. La prensa artística tomó cartas en el asunto para suplir esta carencia lo antes posible; en el ejemplar del 27 de junio de 1847 de $E l$ Renacimiento se incluyó un texto en el que se solicitaba expresamente que se siguiera adelante con el proyecto de erigir un monumento en honor a Velázquez en la capital, partiendo de un modelo en yeso que José Piquer había presentado dos años antes en una exposición del $\mathrm{Liceo}^{91}$. En palabras del autor anónimo de este texto, era deplorable que otros países consideren "como un deber el inmortalizar con mármoles y bronces á todos los genios, sin distincion de naciones", mientras que en España "¡todavía dudamos si deberemos alguna muestra de agradecimiento y veneracion á la memoria de aquellos por cuyas obras no se cuenta entre el número de los pueblos salvajes!"92. No obstante, habría que esperar bastantes años para que el proyecto de un monumento a Velázquez se llevara a cabo en la capital, concretamente hasta que en 1899 se erigió junto al Museo del Prado la célebre escultura realizada por Aniceto Marinas y elevada sobre un pedestal diseñado por Vicente Lampérez ${ }^{93}$. Aunque exceda los límites cronológicos de nuestro estudio, creemos necesario destacar que su tipología difiere de las tratadas hasta ahora

${ }^{91}$ Ya en su momento ese modelo le había granjeado muy buenas críticas a Piquer y había sido difundido por revistas como El Laberinto, que ofreció una estampa de la obra a sus lectores el 16 de mayo de 1844 .

92 "República de artes y letras. Sobre el proyectado monumento á la memoria de Don Diego Velázquez", El Renacimiento, tomo I, no 16, 27 de junio de 1847, p. 128.

${ }^{93}$ C. REYERO, Op. cit., p. 511. por ser una estatua de bronce sedente, con el pintor acomodado en un asiento con sus útiles de trabajo, y una notable proximidad con el observador debida tanto a la naturalidad de su actitud como a la escasa elevación de este pedestal.

Curiosamente, había otro pintor del Siglo de Oro que no andaba demasiado a la zaga de Velázquez en cuando a la valoración que el siglo XIX hacía de su persona. Nos referimos a Bartolomé Esteban Murillo, muy apreciado en la época isabelina, tanto en España como en el extranjero, a pesar de que en la segunda mitad de la centuria la crítica comenzara a mostrarse más dura con él por considerar que su obra era demasiado edulcorada ${ }^{94}$. En El Mundo Pintoresco encontramos unas menciones muy breves acerca del monumento que se le quería erigir en Sevilla, y para cuya realización se convocó un concurso público al que, según recogía esta revista en su ejemplar del 4 de julio de 1858, se habían presentado seis artistas ${ }^{95}$, resultando ganador a juicio de la comisión presidida por Manuel Cortina el escultor Sabino de Medina, al que se le concedieron cuatro mil reales además del honor de ser el responsable de realizar este proyecto ${ }^{96}$. Su pedestal de mármol es más elevado que el de Velázquez que acabamos de citar, con dos secciones cuadrangulares superpuestas y la efigie de bronce de nuevo en pie, con lo que carece de la proximidad del anterior aunque compartan numerosos rasgos de estilo, como la minuciosa recreación histórica de los ropajes del siglo XVII que ambos llevan.

Este monumento contó desde el primer día con el apoyo del pueblo, tal como dejaba patente el 19 de septiembre de 1858 en esta misma revista un entusiasta poema de Francisco Sánchez del Arco, en el que ce-

${ }^{94} \mathrm{M}$. de los S. GARCÍA FELGUERA, "Imágenes de un pintor: la iconografía de Murillo en el siglo XIX", Cuadernos de arte e iconografía, tomo II, no 4, 1989, pp. 324-330.

${ }^{95}$ Z. RUBIO, "Revista universal. España”, El Mundo Pintoresco, ํo 24, 4 de julio de 1858, p. 98.

${ }^{96}$ Ibídem, no 24, 19 de septiembre de 1858, pp. 185-186. 
lebraba que la ciudad de Sevilla contara con un monumento como este, dedicado a uno de sus paisanos más sobresalientes ${ }^{97}$. A pesar de todo, hubo voces que se elevaron contra la primitiva decisión de disponer la escultura en el centro de la conocida actualmente como Plaza Nueva, como la de un autor que publicó en El Mundo Pintoresco del 27 de mayo de 1859 un texto bajo las iniciales $\mathrm{M}$. C. de R. En él proponía reservar ese puesto, de gran importancia dentro del urbanismo sevillano por estar situado delante del ayuntamiento, a un monumento de Fernando III el Santo, alrededor del cual podría disponerse el de Murillo junto con otros dedicados a otros tantos hijos de Sevilla, o bien trasladar el del pintor a otro lugar. M. C. de R. decía:

“Sevilla, cuyos monumentos públicos son un vasto museo artístico y arqueológico, cuyos anales fatigan á la historia, cuyos hijos famosos forman una espléndida galería, debe en concepto nuestro guardar el centro de su magnífica Plaza Nueva para un hombre á quien no dio cuna, pero quien recibió el glorioso pendon que guarda. Murillo es una de las mayores ilustraciones de su noble patria: para nosotros no es solo un gran pintor; es el príncipe de los pintores, y escitará nuestro amor propio nacional el ver su efigie en la ciudad insigne donde vió la luz primera. Pero en ella hay otras grandes plazas públicas, y sobre todo hermosos paseos, donde pudiéramos admirarla y donde fuera estímulo para los que se dedican á seguir las huellas del celebérrimo artista" ${ }^{\prime 98}$.

"Si es gloria de Sevilla y de España y del mundo artístico", seguía diciendo este autor acerca de Murillo, Fernando III el Santo lo era "de toda la cristiandad, es héroe inmortal de la patria, insigne santo y conquistador de la reina del Guadalquivir" ${ }^{\prime 99}$.

${ }^{97}$ F. SÁNCHEZ DEL ARCO, “A Murillo, con motivo de la erección de su estatua en Sevilla", El Mundo Pintoresco, tomo II, nº 41, 9 de octubre de 1859 , p. 326.

${ }^{98}$ M. C. de R., "Monumento á Bartolomé Esteban Murillo", El Mundo Pintoresco, tomo II, nº 13, 27 de marzo de 1859, p. 99.

${ }^{99}$ Ibídem.
Y tal como se observa en la actualidad, su propuesta no cayó en saco roto: hoy en día el centro de la Plaza Nueva se encuentra ocupado por la estatua ecuestre del monarca, mientras que la de Murillo preside la Plaza del Museo, un enclave por lo demás muy adecuado teniendo en cuenta la cantidad de obras del artista que hay expuestas en la pinacoteca $^{100}$.

También en la capital se colocaría una escultura de Murillo, en este caso delante del Museo del Prado, copiada de la que Sabino de Medina realizó para Sevilla. Contaba con un pedestal de sección cuadrangular de cuatro cuerpos, diseñado por el arquitecto Demetrio de los Ríos y realizado en mármol con elementos ornamentales de bronce; y la postura coincide en todo con la sevillana, con Murillo apoyando la mano izquierda en un estrado sobre el que descansan un boceto pictórico y una paleta. Como se trata de un monumento inaugurado en 1871 durante el reinado de Amadeo de Saboya ${ }^{101}$, apenas hemos encontrado información sobre él en la prensa isabelina, nada más que una mención breve, cinco años anterior, en La Revista de Bellas Artes del 9 de diciembre de 1866. En ella se anunciaba someramente que la Real Academia de Bellas Artes de San Fernando había aprobado un proyecto de pedestal "para las estátuas de los célebres pintores Velazquez y Murillo, que el Ayuntamiento intenta colocar frente al Museo de pinturas" ${ }^{\prime 102}$. Nada se nos dice sobre las estatuas propiamente dichas, ni sobre quiénes eran los artistas a los que se había encargado su realización ${ }^{103}$, pero el hecho de que se tra-

${ }^{100}$ N. SALAS, Sevilla: crónicas del siglo XX, T. I, Sevi1la, 1999, p. 39.

${ }^{101}$ J. E. GARCÍA MELERO, Literatura española sobre artes plásticas, tomo II. Bibliografía aparecida en España durante el siglo XIX, Madrid, 2012, p. 153.

102 Nota aparecida en La Revista de Bellas Artes, tomo I, no 10, 9 de diciembre de 1866, p. 76.

${ }^{103}$ Como decimos, el autor original de la efigie de Murillo era Sabino de Medina, mientras que el escultor que se ocupó de la de Velázquez, inaugurada mucho más tarde, en 1899, fue Aniceto Marinas. Los diseños de 
tara de nuevo de Velázquez y Murillo pone de manifiesto hasta qué punto se les consideraba dos de los mayores genios artísticos que había dado la nación, merecedores de ser inmortalizados doscientos años más tarde mediante estos monumentos colocados en la corte madrileña.

\section{CONCLUSIONES}

El análisis de los artículos aparecidos en la prensa sobre este particular nos permite alcanzar una serie de conclusiones bastante clarificadoras. En primer lugar, queda más que patente que la prensa artística se convirtió durante el reinado de Isabel II en una fiel receptora de las ideas acuñadas con respecto a la escultura conmemorativa. El enorme interés que despertaban estos monumentos encontró su eco en publicaciones como El Mundo Pintoresco, Semanario Pintoresco Español, La Revista de Bellas Artes y tantas otras relacionadas con el mundo artístico. Hemos visto cómo hacían referencia a obras pertenecientes a cada una de las categorías que hemos tratado, aunque salta a la vista que hubo dos de ellas que llamaron especialmente la atención de los redactores de estos artículos: la escultura conmemorativa de la monarquía, como no podía ser de otro modo teniendo en cuenta su carácter doctrinal, y la dedicada a personalidades relevantes del mundo cultural. Esto último resulta curioso si evaluamos la importancia histórica que tuvieron Murillo o Velázquez, por ejemplo, en comparación con Colón, pero no debería parecernos extraño teniendo en cuenta que estas publicaciones se dedicaban a las Bellas Artes, y por lo tanto estaban deseosas de ensalzar a quienes despuntaron en este campo.

Tampoco podemos decir que alguna de ellas reprodujera un discurso detallado acerca de la situación de la escultura conmemorativa en aquellas fechas. Se trataba de un tema tan asimilado por la sociedad isabelina

los pedestales a los que se refería La Revista de Bellas Artes fueron realizados por Juan José Sánchez Pescador en el primer caso y por Lampérez y Romea en el segundo. C. REYERO, Op. cit., pp. 504 y 511. que no parecía necesario explicar a los lectores por qué los personajes de estos monumentos eran dignos de admiración. Con la excepción de algunos artículos dedicados a obras concretas en los que se incluían breves reflexiones al respecto (como el de El Mundo Pintoresco que se ocupaba del monumento a Murillo ${ }^{104}$, o el de La Revista de Bellas Artes que hacía lo propio con el proyecto para el de Colón, Cortés y Pizarro ${ }^{105}$ ), el papel que la escultura conmemorativa desempeñaba en la sociedad española decimonónica no era tratado en la prensa de manera sistemática. Y, de hecho, pasarían aún bastantes años hasta que los estudiosos del arte se encargaran de analizarlo desde una perspectiva más moderna, como queda patente en el discurso de Miquel Blay i Fàbregas en la Real Academia de Bellas Artes de San Fernando en 1910 ${ }^{106}$.

Lo que encontramos por lo tanto en las revistas artísticas isabelinas son sobre todo descripciones de los monumentos, en las que tampoco se profundizaba tanto como para establecer una categorización, ni analizar los pros y contras de cada una de las tipologías escogidas. La mayor parte de las críticas que se les hacían, tanto buenas como malas, se relacionaban siempre con lo mismo: el parecido de la escultura con el representado, el mérito de la obra en sí misma y el carácter escenográfico que se le había dado, siendo este último aspecto de gran importancia dentro del discurso expresivo del siglo XIX. De ahí las numerosas referencias a la colocación de las esculturas sobre pedestales que a menudo no eran del gusto de la sociedad, como demuestra por ejemplo el artículo de El Artista sobre el monumento a Cervantes de Antonio Solá; este caso es especialmente significativo porque trataba un tema, el de la elevación de los pedestales,

${ }^{104}$ M. C. de R., "Monumento á Bartolomé Esteban Murillo", El Mundo Pintoresco, tomo II, no 13, 27 de marzo de 1859, p. 99.

105 "Más sobre la erección de un monumento á Colón, Cortés y Pizarro", La Revista de Bellas Artes, tomo I, no 17, 26 de enero de 1867, p. 135.

${ }^{106}$ M. BLAY I FÀBREGAS, Op.cit. 
que resultaba bastante delicado por la excesiva distancia que muchas veces establecía entre la escultura y la sociedad. Del mismo modo, también encontramos numerosas referencias acerca de los materiales empleados en estas obras, aunque las diferentes capacidades expresivas del mármol y el bronce, por poner un ejemplo muy visual, no tuvieran tanta importancia para nuestros autores como la riqueza de los mismos o el acabado final del monumento.

Mención especial merece la atención que estos artículos prestaban a los artífices de las obras. Aunque la escultura conmemorativa, como explicamos al comienzo de nuestro estudio, fuera el escalafón más alto en la carrera de un escultor en la España isabelina, lo cierto es que muchos de estos textos se ocupaban más de la personalidad de los representados que de los artistas, algo hasta cierto punto lógico pero que no deja de resultar curioso. Por supuesto, hay excepciones como el mismo Solá del que acabamos de hablar, pero, por lo general, lo único que se hacía era dejar constancia del nombre de los escultores y del talento que demostraban tener. Hay que tener en cuenta asimismo que, dado que muchos de estos textos eran realmente breves, simples notas en las que se informaba del encargo de una de estas obras, de su conclusión o de su inauguración, no tenía mucho sentido detenerse a analizar la producción artística de un escultor que aún no había demostrado ser capaz de realizar un monumento destinado a convertirse en un hito para su ciudad. Por otro lado, esas inauguraciones a las que nos referimos sí poseían una gran importancia, teniendo en cuenta la pasión por las ceremonias que sentían los españoles del siglo XIX, y la dimensión social que alcanzaban los monumentos desde el instante en que se retiraba una lona y la escultura quedaba expuesta a los ojos de toda la ciudad. Incluso existen casos, como el del monumento a los Héroes del Dos de Mayo, que por la trascendencia histórica del tema representado se convertían en protagonistas de más ceremonias aparte de la de su inauguración, actuando como una suerte de Meca profana a la que se animaba a los españoles a acudir año tras año en las mismas fechas ${ }^{107}$.

Resulta incuestionable, a raíz de lo que hemos enumerado, que la prensa artística actuó como una magnífica receptora de la problemática de la escultura conmemorativa, y al mismo tiempo como una de las mejores herramientas para el adoctrinamiento de la sociedad a través de ella. La revalorización de los momentos de mayor esplendor de la nación, y el afán por ensalzar a los personajes que los habían protagonizado, encontraban su eco en estos artículos, mediante los cuales el pensamiento nacionalista característico de la época isabelina conseguía calar aún más en los lectores. Tan imbuidos del espíritu patriótico como cualquier español, los autores de los textos que hemos analizado veían en la escultura conmemorativa tanto un motivo de orgullo social como una enseñanza plasmada en mármol y bronce, la inspiración de la que tenía que servirse España en el siglo XIX si quería recuperar el esplendor que había tenido en el pasado, y demostrarse a sí misma y al resto de naciones que aún era más que capaz de realizar grandes hazañas.
${ }^{107}$ F. UTRERA, "El dos de mayo", El Mundo Pintoresco, $\mathrm{n}^{\circ} 4,2$ de mayo de 1858, pp. 25-26 y 29 . 